\title{
THE STRUCTURE, BIONOMICS AND FOREST IMPORTANCE OF CRYPHALUS ABIETIS RATZ.
}

\author{
By WALTER RITCHIE, B.Sc., B.Sc. (Agr.), \\ Carnegie Research Scholar in Entomology, University of Edinburgh.
}

Amonast systematists who have worked on the Scolytid or bark-boring beetles there are great differences of opinion as to the limits of the genus Cryphalus. Following Fowler ${ }^{1}$ the genus comprises 24 different species which are widely distributed throughout the world. In his Coleoptera of the British Isles he records six different species some of them amongst the smallest of our indigenous beetles. All of them are of economic importance in forestry. Of our native species two, Cryphalus abietis Ratz. and Cryphalus piceae Ratz., choose as their hosts coniferous trees; the others are found on broad-leaved species.

Till quite recently these two coniferous species were considered rare in Britain but the increasing number of records of C. abietis in Scotland makes it no longer possible to describe this beetle as rare.

In view of new schemes of afforestation it is urgent that we should have exact information on the relative forest importance of the various insect enemies of trees. Further, for purposes of intelligent control a knowledge of the species in its varions stages and of its life-history and habits is necessary. With these principles in view the following research on $C$. abietis was undertaken.

The research is based on an investigation of its life-history and habits, carried out by means of observations and control experiments, conducted in the open at Aboyne, Aberdeenshire, and Banchory-Devenick, Kincardineshire, and of a series of anatomical studies and breeding experiments made in the laboratory at Edinburgh University on and with material collected in the woods in the vicinity of the places named above and in the neighbourhood of Edinburgh.

Following Fowler the genus Cryphalus possesses the following characters: (1) eyes entire or slightly emarginate, (2) antennae with the sutures of the club distinctly marked, the club itself being somewhat variable in shape, (3) thorax tuberculate in front, margined at base,

${ }^{1}$ Fowler's Coleoptera of the British Isles, v, 428-430. 
(4) scutellum small punctiform, (5) elytra not excavate at apex, clothed with a scale-like pubescence and sometimes in addition with fine raised hairs.

\section{DESCRIPTION OF C. ABIETIS RATZ.}

The following is Fowler's 1 description:

C. abietis Ratz. (Fig. 1). Oblong, subcylindrical, compressed and very convex : fuscous or fuscous-brown, dull, antennae and legs reddish-

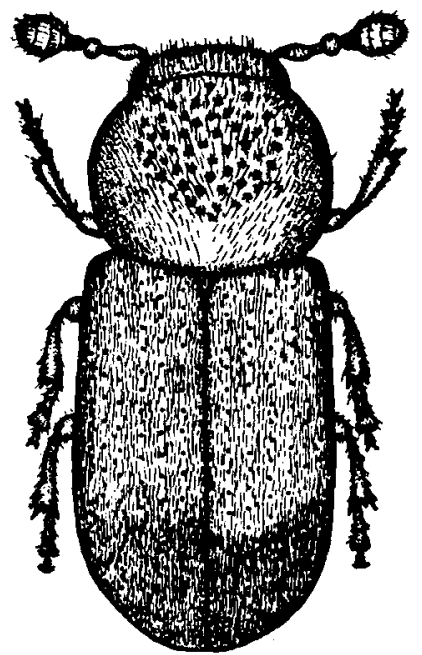

Fig. 1. Adult of Cryphalus abietis Ratz. (greatly magnified).

brown, club of the former usually darker, rounded at apex: thorax subglobular, very finely punctured at sides and behind, front part confusedly granulate: elytra rather more than double as long as thorax with distinct punctured interstices, covered throughout with extremely short scale-like hairs, and also very diffusely with short erect hairs, which are wanting behind: the colour of the antennae and the legs is somewhat variable: the species may easily be recognised by the tubercles on the anterior portion of the thorax being few in number and irregular in their distribution and by the regular comparatively strong rows of punctures and very short pubescence of the elytra. I ength 1-23 $\mathrm{mm}$.

My own examination of numbers of $C$. abietis leads me to emphasise the following characters:

(1) Club of antennae rounded at apex, antennal funicle four-jointed (Fig. 2).

1 Fowler's Coleoptera of the British Isles, v, 431-432. 
(2) Tubercles on prothorax irregular in distribution (not in concentric circles) and wide apart.

(3) Elytra covered with very short scale-like hairs, their interstices with a diffuse row of short erect hairs, which are absent on the apical parts.

From the measurement of a large number of specimens of various origin I find the average length to be $1.75 \mathrm{~mm}$.

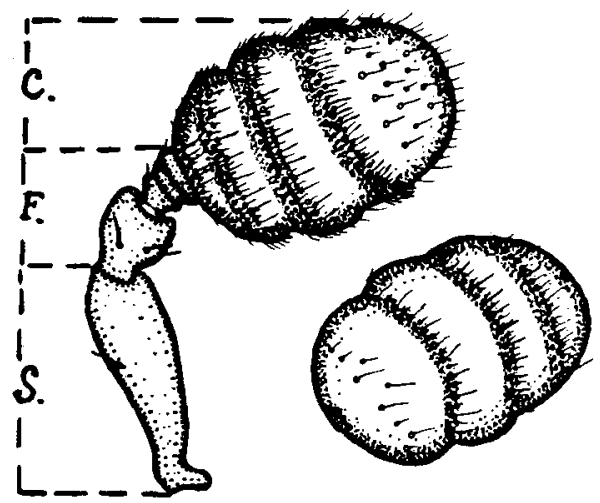

Fig. 2. Antenna of Cryphalus abietis Ratz. Posterior face of club is shown on the right (both greatly magnified). $C .=\operatorname{club} ; F .=$ funicle; $S .=$ scape.

\section{SEXUAL DIFFERENTIATION IN C. ABIETIS.}

There are no reliable external differentiating sex-characters although sometimes the female is slightly larger than the male.

Owing to the close resemblance in feeding habits, similar size, and external naked eye appearance of C.abietis and C. piceae, these two species may be readily confused.

I have compared by aid of the binocular microscope my $C$. abietis with C. piceae from Central Europe in Dr Stewart MacDougall's collection and give in tabular form the outstanding differences between the two beetles.

\section{C. abietis}

Tubercles on prothorax irregular in their distribution (not in concentric circles) and wider apart.

Sides and posterior margin of prothorax bear no marked greyish-white hairs.

Interstices of elytra covered throughout with scale-like hairs, and each has a row of diffuse short erect greyish-white hairs which are absent on the apical parts.

Ann. Biol. $v$

\section{C. piceae}

Tubercles on prothorax fairly regular in their distribution (in concentric circles) and closer together.

Sides and posterior margin of prothorax bear long raised greyish-white hairs.

Interstices of elytra covered with a few scale-like hairs and each has a row of long, raised, greyish-white hairs, which are most marked on the lateral margins and apical portions of the elytra. 
EGG OF C. ABIETIS.

The egg is oval in shape, whitish in colour, translucent; and has a smooth shiny surface. The egg measures about $.6 \mathrm{~mm}$. in length and a little less than $.3 \mathrm{~mm}$. in breadth.

\section{LARVA OF C. ABIETIS (Fig. 3).}

The larva, in general appearance, is typically Scolytid. It is a soft legless grub, with a curved body. The colour of the larva is yellowishwhite save the hard chitinous head and mouth-parts which are darkish brown. The body is much wrinkled, with fine hairs scattered over it.

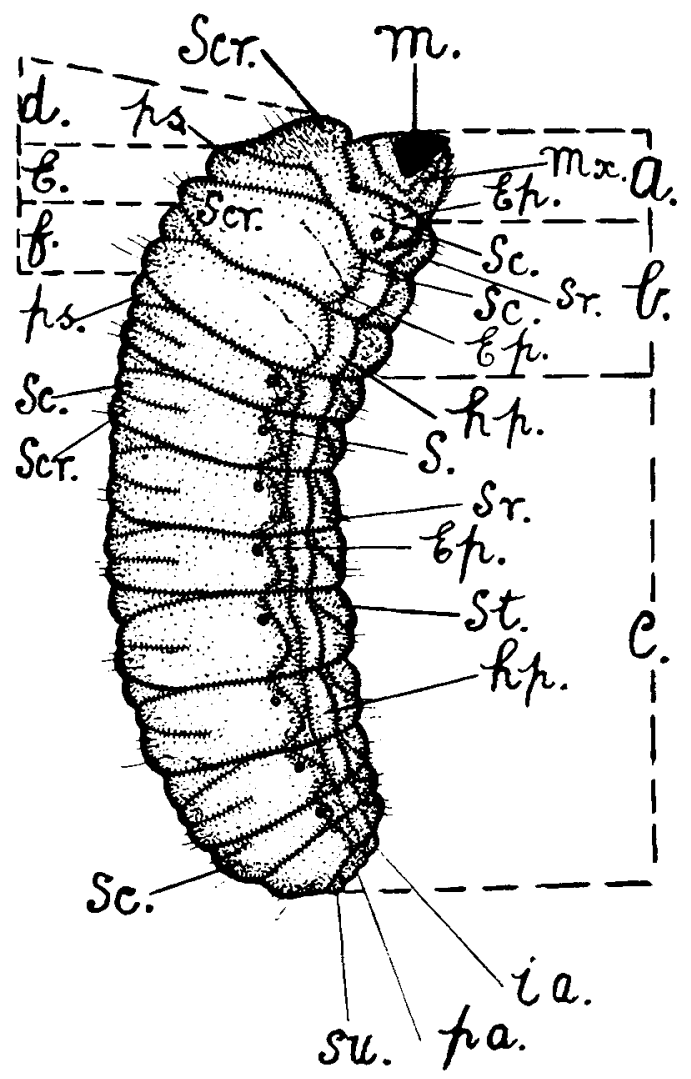

Fig. 3. Larva of C.abietis, side view (greatly magnified).

The larva is made up of the oblong chitinous head-piece-two-thirds of which is retractile within the first body segment or prothorax-and thirteen distinct body segments. The first three body segments form the 
thorax, the other ten the abdomen. The thoracic segments are larger than the abdominal ones. The first segment of the thorax is more flattened dorsiventrally than the others and bears on its dorsal surface a rectangular patch covered with a felt of fine reddish-brown hairs. The 8th and 9th abdominal segments are much smaller than the others. In a ventral view (Fig. 7) the 10th or last segment is seen to consist of four distinct lobes around the anus. Spiracles, circular in shape, are present on the first thoracic segment and the first eight abdominal ones. The length of the full-grown larva is, on an average, $2.25 \mathrm{~mm}$.

\section{Head of Larva (Fig. 4).}

With the aid of a binocular microșcope the following parts can be made out in a dorsal view.

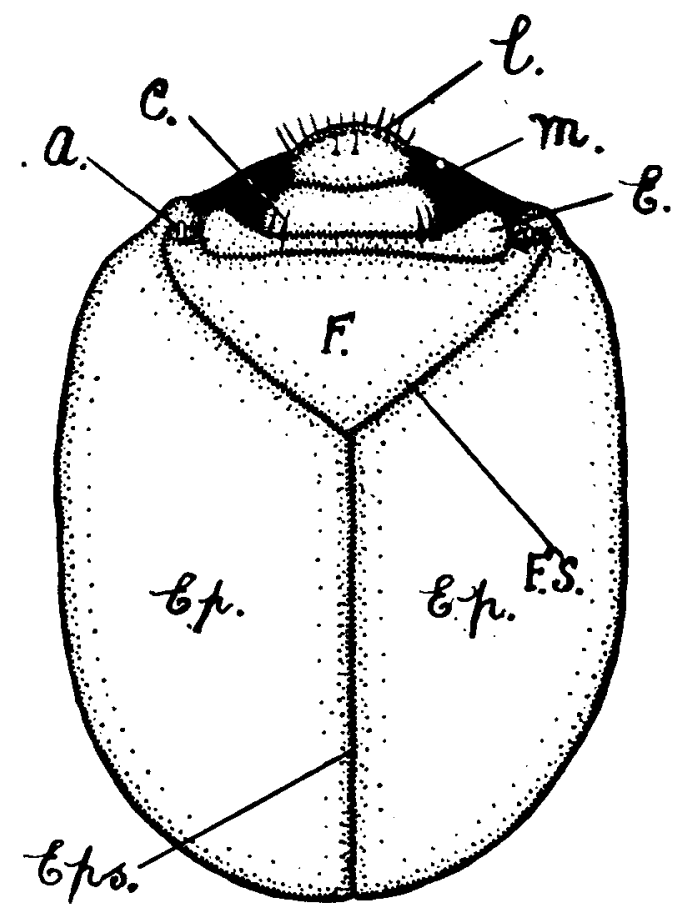

Fig. 4. Head of larva of C. abietis seen from above (greatly magnified).

Most anteriorly lies the labrum (l.) or upper lip which bears a number of fairly strong bristles on its front margin. Posterior to the labrum lies the clypeus $(c$.) while still further back may be seen the epistome $(E$.), a thickened band of chitin carrying a few strong bristles and forming a 
support to the clypeus. At each end of the cpistome lies a single-jointed antenna (a.) sunk in a pit. In each pit, externally to the antennae four chitinous bristles are usually placed. These details are more clearly shown in the enlarged view of the epistomal region (Fig. 5). In this figure $E p$. stands for epistome.

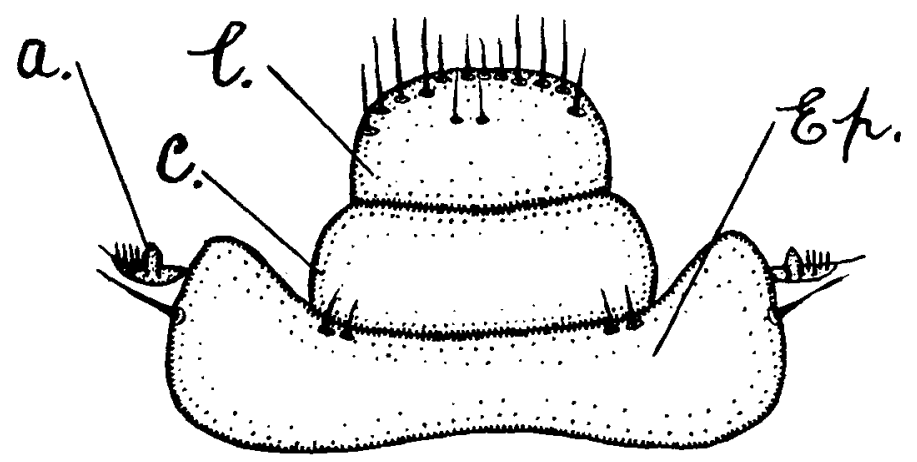

Fig. 5. Region of epistome of C. abietis larva (greatly magnified).

Posterior to the epistome and adjacent to it lies a triangular area, the frons $(F$.$) , bounded on each side by the frontal sutures (F . S$.$) . On$ each side of the frontal sutures lies the epicranium $(E p$.$) , a large area$ which occupies the greater portion of the surface of the head. The epicranium in turn is divided posteriorly into two parts by the epicranial suture (Ep.s.).

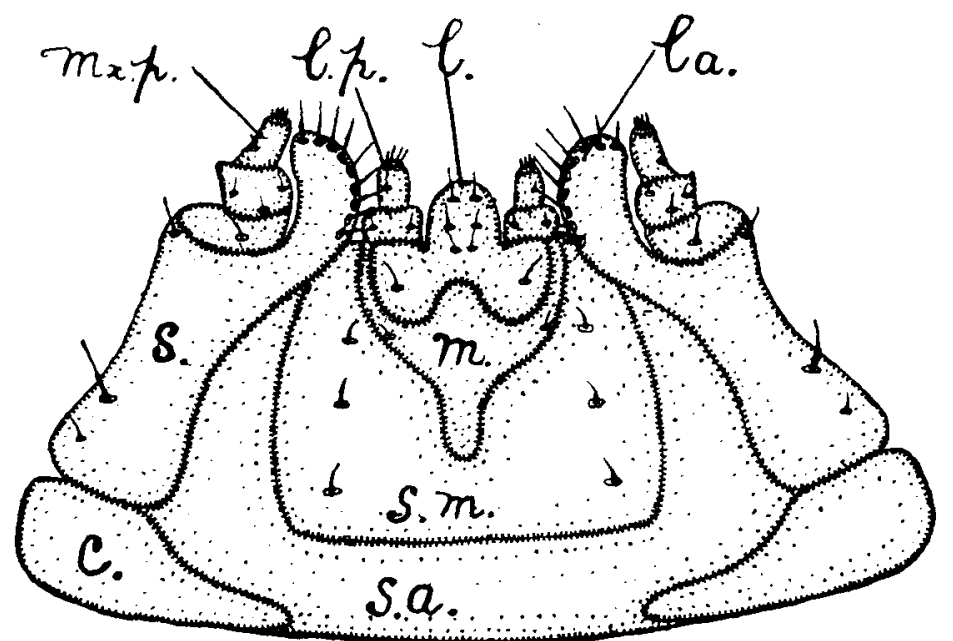

Fig. 6. Maxillue and labium of larva of C. abietis (greatly magnified). 
On each side of the labrum and partly overlapped by it, are the mandibles. Each mandible $(m$.) is dark brown in colour, highly chitinized and bears three teeth, the posterior one being the smallest.

On the ventral aspect of the head lie the maxillae (Fig. 6).

1st Maxillae: These lie one on each side of the labium and are composed of the usual three parts: posteriorly the cardo $(c$.$) , more anteriorly$ the stipes (s.), bearing a three-jointed maxillary palp (mx.p.) and a few scattered bristles, and thirdly the lacinial lobe (la.) which has a number of stout chitinous bristles on its outer margin.

2nd Maxillae: In the centre of the field lies the labium or fused 2nd maxillae, made up of the mentum (m.) with two labial palps (l.p.) each two-jointed and with the ligulae $(l$.$) lying between them. Posterior to$ the mentum is the submentum (s.m.), often indistinct from the submental area $(s . a$.$) which lies still further back.$

\section{The Thorax (Fig. $3 b$ ).}

The thorax of the larva is made up of the usual three segments, namely the prothorax, lying behind the head, the mesothorax, and the metathorax.

In a side view of the prothorax (Fig. $3 d$ ) one can make out the following five folds: the scutellar (scr.) forming the dorso-lateral portion and bearing the rectangular patch of fine hairs already referred to; the scutal $(s c$.) bearing a spiracle on its most ventral portion; the epipleural (ep.) and the hypopleural ( $h p$.) forming the lateral portion (the two last-named folds are more ventral than the first); the sternellar (sr.) forming the ventral portion.

The mesothorax (Fig. $3 e$ ) in side view shows six folds: the prescutal (ps.) forming the anterior dorsal portion: the scutellar (scr.) forming the dorso-lateral portion: the scutal (sc.), epipleural (ep.) and hypopleural $(h p$.$) forming the lateral portion; the sternellar (s r$.$) forms the ventral$ portion. There are no spiracles borne by the mesothoracic segment. The metathoracic segment (Fig. $3 f$ ) is similar to the mesothoracic in structure and is of a corresponding size and shape.

The Abdomen (Fig. 3 c).

The first seven abdominal segments are similar in structure although they vary in size. In side view each segment shows seven folds: the prescutal ( $p s$.$) , scutal (sc.) and scutellar (scr.) form the dorso-lateral$ portion; the epipleural $(e p$.$) and the hypopleural (h p$.) form the lateral portion: while the sternal (st.) and the sternellar ( $s r$.) form the ventral portion. On each segment, between the epipleural (ep.) and the scutal 
(sc.) and scutellar (scr.) folds there is a deep crescent-shaped hollow or groove; on the anterior dorsal side of this groove lies a spiracle (s.).

The 8 th abdominal segment, in side view, shows a similar composition to the first seven segments except that the prescutal and the scutellar folds are just traceable. The 9 th abdominal segment is similar to the 8th except that the prescutal fold is absent and there are no spiracles. The loth segment, in side view, shows three lobes surrounding the anus; the infra-anal lobe $(i u$.) situated ventral to the anus; the supra-anal (su.) dorsal and the para-anal ( $p a$.) between the above two.

Looking at the larva from the ventral side (Fig. 7) two other folds may be seen on the thoracic segments, namely the sternal (st.) and the poststernellar $(p s$.$) .$

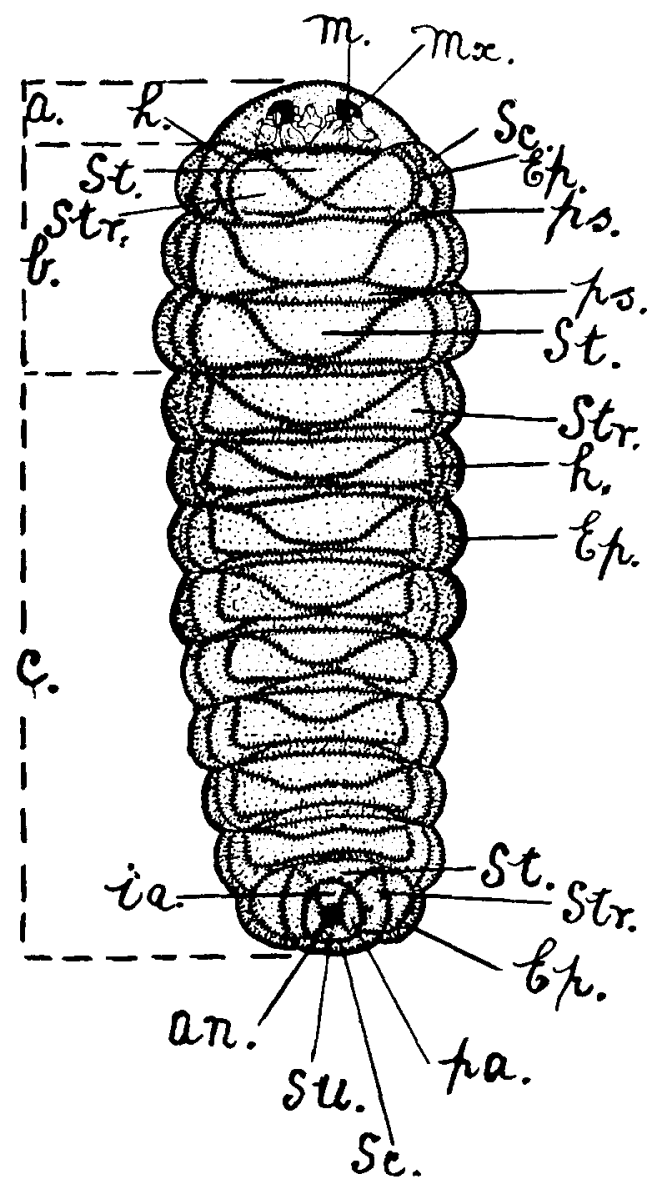

Fig. 7. Ventral aspect of larva of C. abietis (greatly magnified). 
In a ventral view of the abdomen (Fig. $7 c$ ) one other fold, namely the poststernellar, is discernible in addition to those already seen in the side view. The poststernellar fold is present in all the abdominal segments except the last three: in the 8th and 9th it is absent: in the 10th both poststernellar and sternal folds are wanting. In this figure Str. stands for sternellar fold and $h$. for hypopleural fold.

THE PUPA OF C. ABIETIS.

At first the pupa has the general colour of the larva but soon darkens, the mandibles being the first of the appendages to reveal themselves as two brownish patches.

In a dorsal view of the pupa the main divisions of the body are visible. On the vertex or front portion of the head one can make out a few frontal spines. These are fairly conspicuous and are widely separated.

On the sides of the pronotum may be seen a few scattered spines. Lying at the base of the elytra is the scutellum which is easily distinguishable.

Rows of dorsal and pleural spines are absent on the dorsal and lateral surfaces of the abdominal segments, a noteworthy feature as these spines are usually present on the corresponding parts of many Scolytid pupae.

On the ventral aspect of the pupa the usual appendages on the several divisions of the body can be made out. On the head portion the antennae and at the base of the antennae the eyes; lying posteriorly the gena or cheek region between the antenna and the labrum; mandibles, lst maxillae and labium are also distinguishable.

The legs are folded along the surface of the body, the last pair for the most part obscured from view by the overlapping elytra. On the abdomen only the last few segments are visible in the ventral view; the 9th bearing two prominent fleshy projections or spines is the most conspicuous one. The presence of these spines is characteristic of Scolytid pupae.

On each side of the body lies an elytron or wing cover from under which projects the tip of a flying wing.

THE BROOD GALLERIES OF C. ABIETIS (Fig. 8).

In some of our bark-boring genera the parent beetles make a comparatively straight strong burrow or mother gallery. Unlike these the typical mother gallery of $C$. abietis rather takes the form of a circular burrow which is cut or gnawed round the base of a branch or twig. If 
the branch round which the burrow is cut happens to be a fairly strong one it may be only partially eaten round. On the other hand, if the branch be weak, as is very often the case, the burrow completely girdles the branch. The length of the gallery varies. When the mother gallery is short it is broader, when long it is usually narrower. On an average the distance between the beginning of the mother gallery and its termination, measured along its course, is about $\frac{3}{4}$ inch in length, while in breadth it measures from $\frac{1}{8}-\frac{3}{16}$ inch.

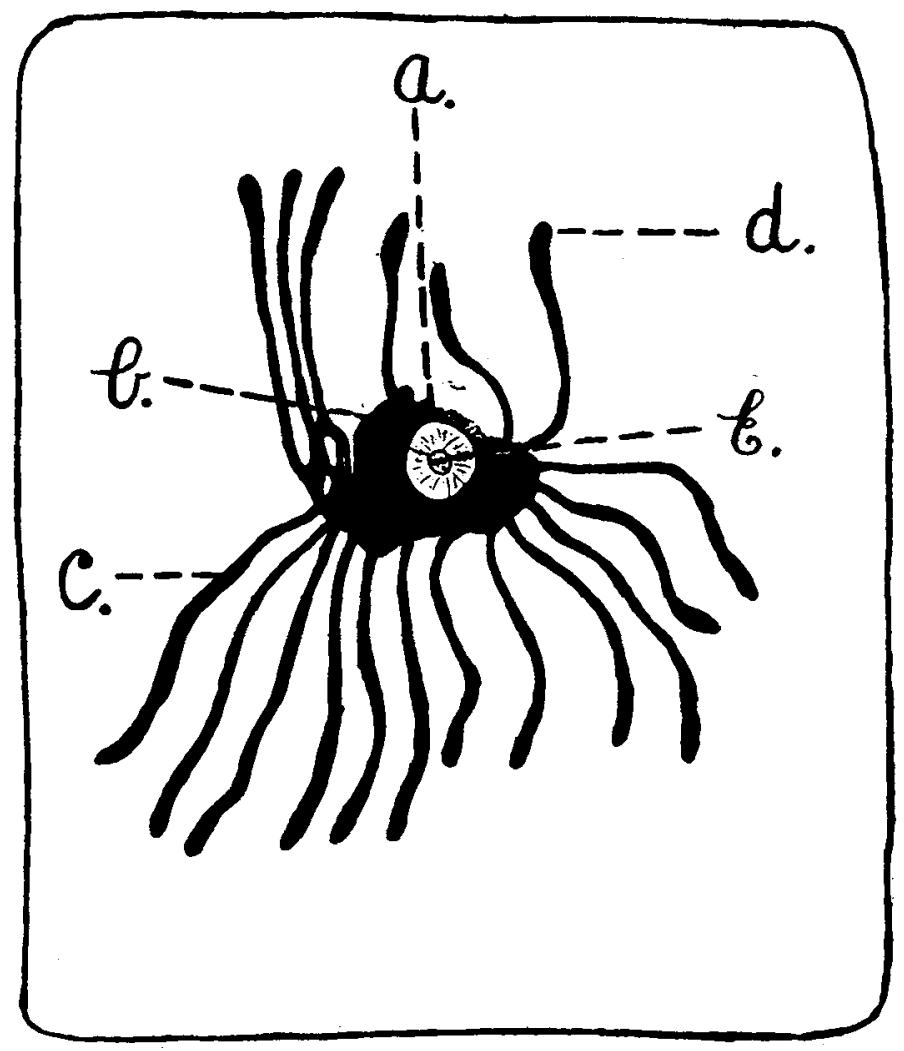

Fig. 8. Typical brood galleries of C. abietis on a branch of Silver Fir (Abies pectinata D.C.). Note how the mother gallery is cut round a smaller branch $(E$.$) . a$. = beginning of mother gallery; $b .=$ mother gallery widened in parts through the feeding of the young larvae; $c .=$ larval gallery; $d .=$ pupal bed; $E .=$ base of smaller branch round which mother gallery is cut.

The larval galleries naturally run almost at right angles to the mother gallery, radiating out from it on all sides. Some of these larval galleries 
run vertically upwards along the main branch, others run vertically downwards, while others run obliquely. Very frequently the larval galleries run along the branch or twig the base of which has been girdled by the mother gallery. The larval galleries, like the mother galleries, vary considerably in length. The shortest one I have measured was about $\frac{1}{2}$ inch in length, while the longest was about $1 \frac{1}{2}$ inches.

As is usually the case in monogamous species of Scolytids the female does all the work in the cutting of the mother gallery, right from the entrance hole to its terminating point. In a few cases, however, prior to the disappearance of the female underneath the outer bark I found the male cutting a separate hole close beside her, evidently feeding on the gnawed material. As soon as the female had made a burrow long enough to accommodate herself underneath the bark the male at once repaired to her aid and helped her to widen the mother gallery, following her closely, gnawing first at one side of the gallery then at the other. The chief work of the male however is to throw to the outside of the entrance hole of the gallery the fine bore dust, shovelling it out with his legs. The sexes meet on the surface of the bark.

In many genera of Scolytids, e.g. Myelophilus and Tomicus, the eggs laid by the female are deposited in notches cut by her, as she bores, at more or less regular intervals along both sides of the mother gallery. In the case of $C$. abietis the eggs are laid irregularly and no notches are cut by the female; in fact the eggs usually occur in batches. In some cases I found that the female after she had cut a part of the burrow turned back towards the entrance hole and then laid four eggs; after she had laid this set of eggs she again proceeded to tunnel her gallery, returning after a time to lay another set of eggs. The female lays from 14 to 24 eggs and takes from 5 to 7 weeks to complete her gallery.

The larvae when hatched burrow irregularly for some time, eating along the sides of the mother gallery and usually altering its shape. As a result it is often impossible to determine the original shape of the mother gallery after the eggs have hatched. After boring along the sides of the mother gallery for some time the larvae separate and each gnaws a separate burrow in the inner bark layers, feeding on the gnawed material. This gnawed material is passed through the alimentary canal and the undigested waste material fills the burrow behind the larva.

The mother galleries never penetrate the sapwood but show on the inner bark layers. The young larvae while feeding in their tunnels do not cut the sapwood but for some time prior to pupation they often do groove the sapwood. In other cases the larvae do not groove the 
sapwood at all until about to pupate when they invariably cut a pit or bed in the outer surface of the sapwood. This bed or pit excavated by larvae about to pupate lies in no constant direction. Sometimes it may be in the vertical direction, at other times horizontal, and at others oblique.

Thus when a piece of bark is removed from an infested branch the brood galleries cannot be traced on the sapwood at all. As a rule one can trace only that portion of the larval galleries which was cut previous to pupation and the pupal bed or pit on the exposed wood surface. While this is the typical occurrence other appearances are possible. For example, in further observations I noticed that when the bark was somewhat thick, as in the case of strong branches, the larval galleries often did not groove the sapwood at all and usually on these branches pupation took place in the bark. Where the bark was thin on the other hand, as on twigs and on small branches, the larval galleries throughout their entire length grooved the sapwood deeply while the pupal beds in such places were very marked on the surface of the sapwood. As a result when the outer bark was removed from an infested branch with fairly thick bark only the pupal beds could be traced. While if this same operation was performed on an infested twig or weak branch when the bark was thin the larval galleries and pupal beds could easily be traced on the wood surface.

After the period of pupation has passed the young imagos first feed on the patches of the inner bark which surround their pupal beds and then finally bore to the outside through the bark and issue by the small exit holes.

As I point out later in this paper the parent beetles do not all die after egg-laying but in many cases feed anew prior to a possible second egg-laying. I have frequently found these old parent beetles after their egg-laying has been completed cutting galleries which resembled in shape and in direction larval ones.

\section{Irregular Galleries.}

Overcrowding of both mother and larval galleries is not uncommon and takes place on badly infested stems and branches (Fig. 9) with the result that the galleries may be very irregular both in shape and in direction. In many cases it is extremely difficult or impossible to trace, in the confused workings, individual galleries. As a rule on badly infested branches the larval galleries are much shorter than those found on not so badly attacked ones. As a common instance of overcrowding we 
may take the case figured here, where the bases of two branches of the same whorl have each been girdled by mother galleries. Here the larval

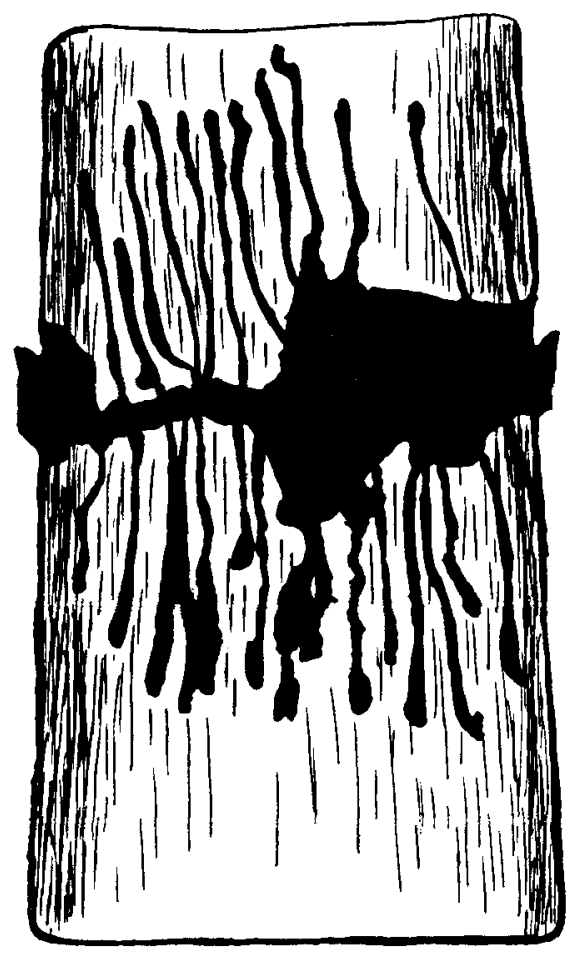

Fig. 9. Piece of branch of Silver Fir with irregular brood galleries of $C$. abietis due to overcrowding. A side view is shown of the bases of two small branches which havo been girdled by mother gallerics-represented in the figure as dark projecting portions one on each side of the main branch. Note how the larval galleries arising from the mother galleries have intermingled and so have completely girdled the main branch. The original shape of the mother galleries is here obliterated completely by young larval galleries (dark patches on the main branch) running together; later the larval galleries separate, running upwards and downwards on the main branch.

galleries which arise from each set of mother galleries usually intermingle and as a result completely girdle the main branch. Further in such cases (see figure) it is quite impossible to determine from which set of mother galleries the larval ones arise.

Even more confused workings than the above example are quite common. For instance, where two or more females have chosen the same axil of the branch or twig for brood purposes, the entrance holes of the mother galleries are very near to one another, which leads to 
great confusion of mother galleries and larval galleries. The galleries in such cases intersect each other in all directions, forming a network underneath the outer bark layer.

Again where the bases of branches of a whorl have already been badly infested by beetles other parent beetles may commence boring brood galleries on the main branch between the whorls. This occurrence is very common on badly infested stems and branches and leads to still greater confusion of brood galleries.

An exceptional irregularity was found where a number of males and females had used the same entrance hole from which to bore their galleries. Each pair of parent beetles entered underneath the bark by this common entrance hole and immediately proceeded to make a separate mother gallery. These mother galleries radiated out in all directions from the common entrance burrow (sce Fig. 10). I have taken as many as five pairs of beetles from such a set of galleries.

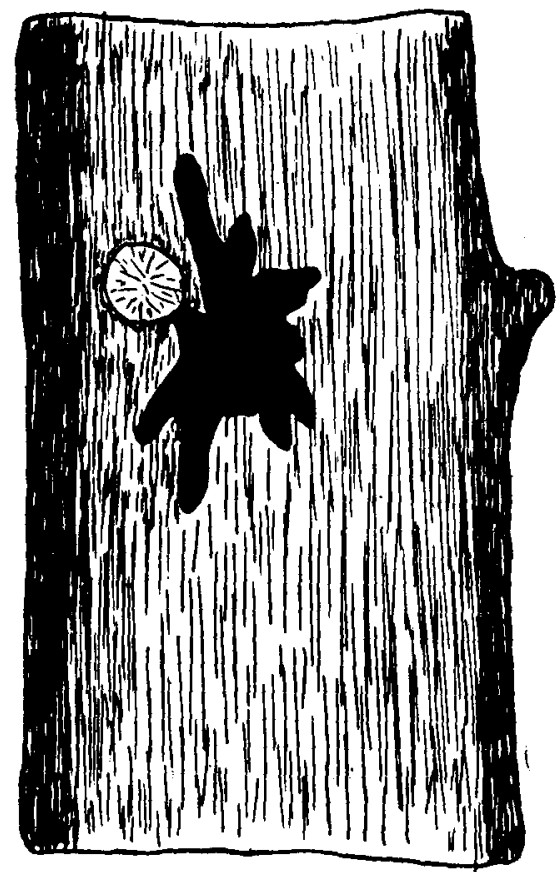

Fig. 10. Irregular mother galleries (not finished) on a piece of Silver Fir stem.

In dealing with the brood galleries of $C$. abietis it is quite impossible in most cases to trace either mother or larval galleries on the removal of the outer bark. 
Instead one usually finds all the inner bark layers converted to dust by the work of parent beetles and their larvae. The best way to ascertain the shape of a typical mother gallery is to dissect the gallery immediately after the female has completed her egg-laying and before any of the eggs have hatched. To trace the larval galleries accurately it is essential in most cases to follow up the larvae as they tunnel their respective galleries.

\section{LENGTH OF LIFE-CYCLE IN A SINGLE GENERATION.}

Many observations repeated under different conditions proved to me that the period of the life-cycle from the laying of the egg to its culmination in the adult stage was extremely variable. The time varied according to the season of the year at which the eggrs were laid, the quality of the food material, and the position of that material with relation to the sun: and consequently the environmental temperature.

In the vicinity of Aboyne, Aberdeenshire, field observations were carried out in early April, 1917, in Silver Fir woods badly infested with Cryphalus abietis. Careful examination was made of all likely places for females to have chosen for new brood galleries but no adults were found at work. The weather up to this time had been exceptionally unfavourable.

On the 28th September, 1916, however, I had collected some badly infested material consisting of branches and twigs from these same Silver Fir woods. Examination of this material at the time of collection showed that Cryphalus abietis was present underneath the bark layers in exceedingly large numbers both as immature fresh young adults and as larvae. This badly infested material-referred to later in this paper as my "stock material" - was kept in the open air throughout the winter months and examined at intervals. On the 20th of April, 1917, one adult issued. Several more adults issued up to 27th April, 1917. Some of these were killed and dissected for the study of their reproductive organs but 50 others were liberated in a muslin bag containing a few branches of Silver Fir and Spruce. These branches had been paraffined at their cut ends to keep them from becoming too dry. This bag was then closed and placed in the open air. Three days later, i.e. on 30th April, 1917, the branches in the bag were carefully examined. Some females had just commenced to bore into the Spruce and Silver Fir branches and in a number of cases the male beetle was found resting on the surface of the bark close by the female. 
In another experiment carried out in a similar method and under similar conditions 60 adults were liberated on May 2nd, 1917. Dissections of many mother galleries were made at intervals with a view to collecting all the data possible on the making of the gallery and the egg-laying.

In one dissection made 16 days after the commencement of the gallery I found one egg laid while in another four eggs were laid by the end of a month.

The incubation period of the eggs was on an average 10 days. Large numbers of adults continued to escape from my "stock material" up to June 15th, 1917.

The time taken by the parent beetles to bore the mother gallery varied from 5 to 7 weeks.

Some larvae fed for 69 days and then pupated, the pupal period lasting about 29 days.

Thus in the case of eggs laid on June 4th, 1917, i.e. a month after the commencement of the mother gallery, the total period until the imago stage was reached on September 21 st, 1917, was 108 days.

In my control experiments in natural conditions, some badly infested Silver Fir branches in the woods at Aboyne examined on June $26 \mathrm{th}, 1917$, were found to contain hundreds of eggs of $C$. abietis and in many cases the females had not yet completed their egg-laying. These branches were examined at intervals throughout the summer and the length of the various stages was found to be as follows, viz. egg on an average 10 days: larva 71 days: pupa 22 days. That is to say the lifecycle from the egg stage at the end of June to the adult stage on September 27 th was 93 days.

While in the above cases many individuals of the same brood reached the adult stage in the average period, quite a number of others were still in the larval stage at the end of September, 1917, and hibernated as larvae.

As showing the variations found in the length of the life-cycle I have set out in the following diagrams the life-cycles which I met with in my control experiments and in the open.

Diagram A.

\begin{tabular}{|c|c|c|c|c|c|c|c|c|c|c|c|c|}
\hline Year & $\begin{array}{c}\text { Jan. } \\
\ldots\end{array}$ & $\begin{array}{c}\text { Feb. } \\
\ldots\end{array}$ & March & Apl. & $\begin{array}{l}\text { May } \\
+ \text { - }\end{array}$ & $\begin{array}{c}\text { June } \\
--\end{array}$ & $\begin{array}{c}\text { July } \\
-\end{array}$ & $\begin{array}{c}\text { Aug. } \\
-0\end{array}$ & $\begin{array}{c}\text { Sep. } \\
0+\end{array}$ & $\begin{array}{c}\text { Oct. } \\
+\end{array}$ & $\begin{array}{c}\text { Nov. } \\
+\end{array}$ & $\begin{array}{c}\text { Dec. } \\
+\end{array}$ \\
\hline 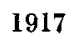 & + & + & + & + & $+\bullet$ & - - & _- & -0 & $0+$ & $\ldots$ & $\ldots$ & $\ldots$ \\
\hline
\end{tabular}




\section{Diagram $B$.}

This diagram is for comparison with Diagram A showing the possible development of the last laid eggs of the same beetles.

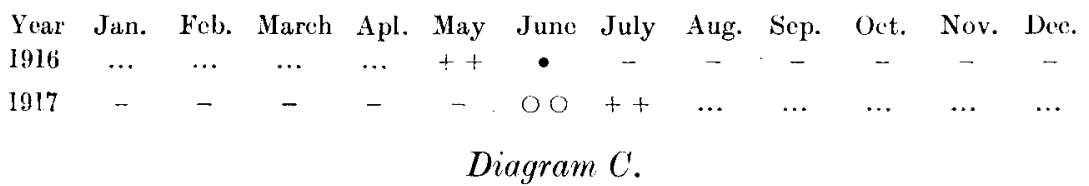

Life-cycle found where the brood material was lying under dense shade and hence summer temperature Jow-here whole of young brood hibernates as larvae.

Year Jan. Feh. March Apl. May June July Aug. Sep. Oct. Nov. Dee.

$\begin{array}{llllllllllllllll}1916 & \ldots & \ldots & \ldots & \ldots & + & \bullet & - & - & - & - & - & - & -\end{array}$

1917

Length of life-cycle, egg to adult, here is about $11 \frac{1}{2}$ months.

Diagram $D$.

Exceptional case in length of life-cycle--here brood material was of poor quality and in dense shade.

Year Jan. Feb. March Apl. May June July Aug. Sep. Oct. Nov. Dec.

$\begin{array}{llllllllllllll}1916 & \ldots & \ldots & \ldots & \ldots & \ldots & \ldots & + & \bullet & - & - & - & - & -\end{array}$

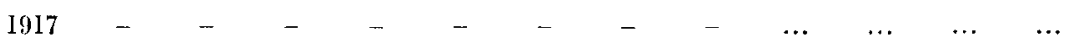

From the diagrams it will be seen that the length of the larval period is extremely variable. In the typical life-cyele it is from 69 to 71 days, whereas where the beetles hibernate as larvae it may be about $11 \frac{1}{2}$ months or longer.

Further, it is obvious that owing to this great variation in the length of the life-cycle there is a great deal of overlapping of generations of beetles.

\section{LENGTH OF LIFE OF C. ABIETIS AND THE NUMBER OF GENERATIONS IN A YEAR.}

It is now recognised amongst workers on Curculionids and Scolytids that many of these beetles may not only have a long individual life but that the newly issued young brood of beetles cannot proceed at once to an efficient copulation followed by egg-laying. Eichhoff and his school believed the contrary. More recent workers however, including Von Oppen, Nusslin, and MacDougall for Curculionidae, and Pauly, Nusslin and Knocke and Fuchs for Scolytidae, proved that Eichhofl's view was erroneous. 
My own recent work ${ }^{1}$ on the Scolytids Myelophilus piniperda Linn. and Myelophilus minor Hart. has corroborated the view of these later workers. From the results of the researches of these workers it has also been definitely proved that a large number of forest insects belonging to the Scolytids and the Curculionids do not die after pairing and a first egg-laying, but that after a period of renewed feeding in order to recuperate and to render their sexual organs once more functional, it is possible for them to proceed to a second pairing and a second egglaying. Von Oppen and others also showed that the imago on its transformation from the pupal condition might be quite unripe and unable to proceed to an efficient copulation followed by egg-laying, and that in such a case an intervening feeding period was necessary for the reproductive organs to become mature.

Further, the question of whether two broods in the relationship of parents, children, and grandchildren are possible in a year is greatly dependent on two things, viz. whether a preliminary feeding is necessary before breeding and if this feeding period be short or long. If this feeding period be short then a second brood in the year is possible, whereas if the period is long a second brood is impossible.

The proving of the facts is not an easy matter in the case of $C$. abietis where the most of the feeding previous to exit for mating takes place under the bark in the place where the insect has reached its imago stage. As underneath the bark of an infested branch or stem it is possible to find Cryphalus beetles that have already bred and beetles that have just reached the imago stage and have not bred at all, the true facts as to length of life, number of broods possible, and the generations possible in a year can only be ascertained by a dissection and comparison of the reproductive organs of new imagos, beetles ready to pair, beetles that are laying eggs and beetles that have completed egg-laying.

THE MALE REPRODUCTIVE ORGANS OF CRYPHALUS ABIETIS.

Fig. 11 shows the male reproductive organs dissected out. These comprise the testes, vasa deferentia, seminal vesicles, accessory glands, common vas deferens or duct and the penis. The testes are translucent glandular bodies and as usual one lies on either side of the abdomen ventrally. These produce the spermatozoa. Each testis $(T$.) is made up of two lobes somewhat circular in shape and closely united along their inner surfaces. From the posterior or under side of each testis, a duct

1 Trans. Royal Society Edin. vol. LII, Part 1, No. 10. 
or tube arises known as the vas deferens $(V . d$.$) . The vasa deferentia unite$ later to form a common duct (C.d.) which leads to the penis. The vas deferens is much swollen but there are constrictions on it at two points. The first constriction occurs at a point distant from the testis of about one-quarter of its total length, while the second is at a point about a corresponding distance from the other end of the vas. The first constriction is most marked, the second is not so conspicuous. The swollen

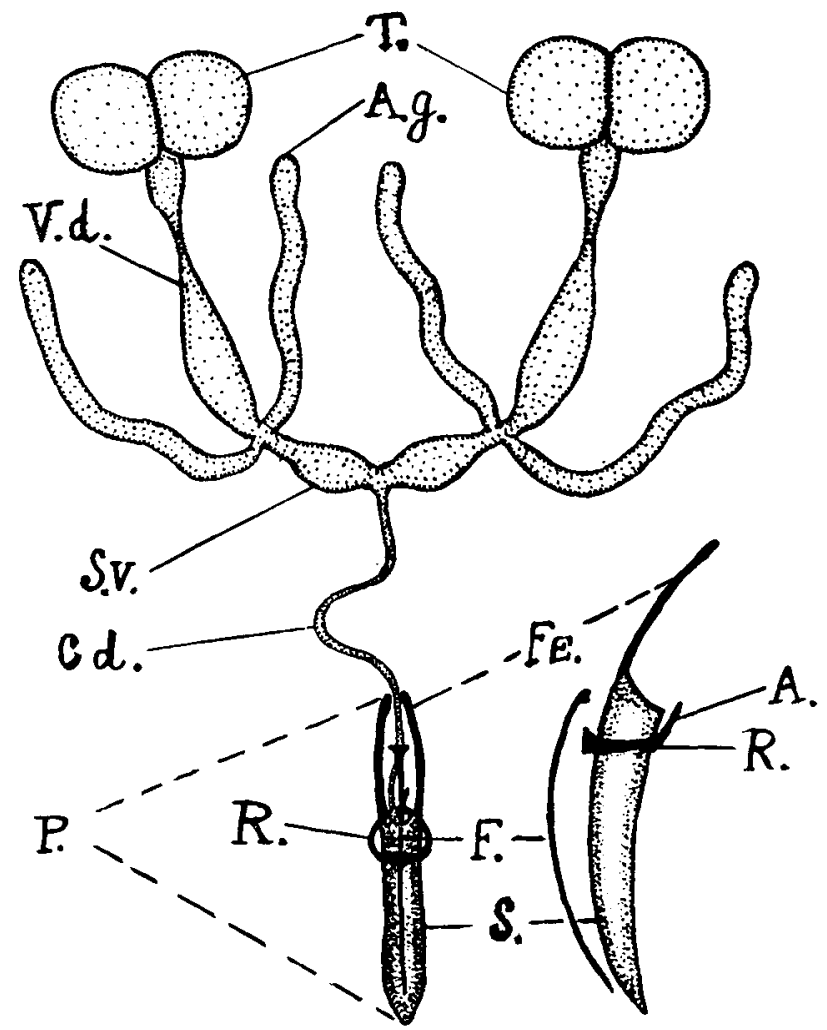

Fig. 11. Male reproductive organs of C. abietis (greatly magnified). On the right the penis is shown in side view (more highly magnified).

portion of the vas lying between the second constriction and its union with the vas deferens from the other testis, i.e. the most posterior portion of each vas, is called the seminal vesicle (S.v.). Two blind diverticula, the accessory glands $(A . g$.$) , one on either side and placed opposite each$ other, open into the vas deferens just at its second constriction. The chitinous portion of the penis $(P$.$) is composed of the fork (F$.), ring $(R$.$) and sheath (S$.$) . The fork gradually tapers to a point while anteriorly$ Ann. Biol. v 
it widens out slightly into a triangular-shaped knob showing very frequently rounded projections on either side. The ring, on the whole, is circular in shape and surrounds the sheath of the penis. In a lateral aspect (Fig. 11) of the chitinous portion of the penis, the dorsal portion of the ring is seen to be drawn out to a point which projects anteriorly. This drawn-out portion of chitin is called by Hopkins ${ }^{1}$ the apodemal process (A.).

The sheath, roughly speaking, may be considered as a hollow chitinous cylinder tapering postcriorly and bearing on its anterior edge two chitinous rods known as the femora (Fe.). In the following columns I contrast the main characters of unripe and ripe reproductive organs of the male, which proved useful to me in differentiating them.

Testes white.

Vas deferens, i.e. portion between testis and seminal vesicle, dirty white in colour.

Șeminal vesicle small.

Accessory glands short and thin, only slightly developed.
Testes yollowish.

RIPE

Vas deferens, i.e. portion between testis and seminal vesicle, yellowish in colour.

Seminal vesicle swollen.

Accessory glands greatly lengthened.

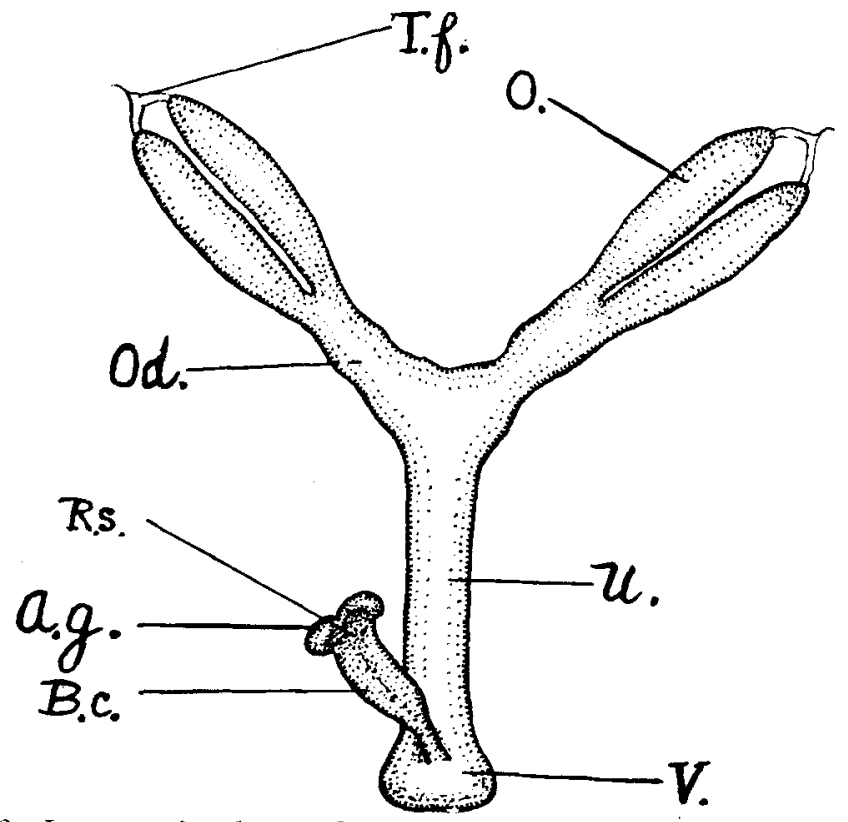

Fig. 12. Immature female reproductive organs of C. abietis (greatly magnified).

1 Hopkins, Preliminary Classification of the Superfamily Scolytoidea, Technical Series, No. 17, Part II, U.S. Bureau of Entomolngy, 1915, p. 193 et seq. 
FEMAIE REPRODUCTIVE ORGANS OF C'. ABIETIS.

Fig. 13 depicts the reproductive organs of a female about to proceed to egg-laying.

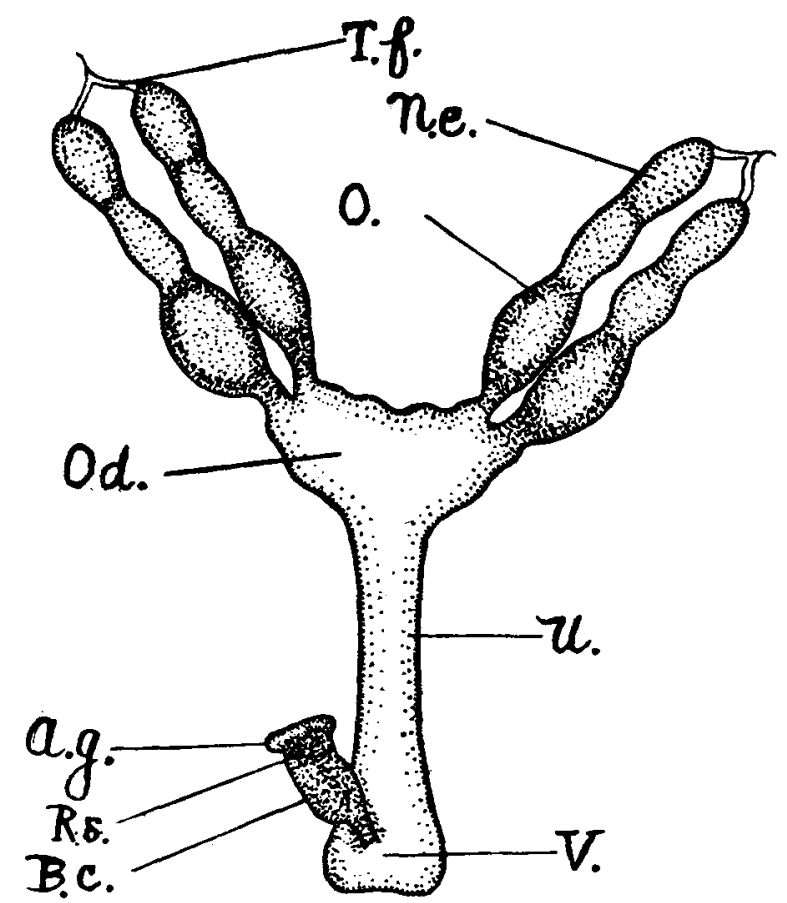

Fig. 13. Reproductive organs of female C. abietis about to lay eggs (greatly magnified).

There are two ovaries, one on each side of the abdomen. Each ovary $(O$.) consists of two egg-tubes, which open into the paired oviduct. At the anterior extremities of each egg-tube there is a terminal nutritive chamber $(N . c$.$) and at its apex a terminal filament (T \cdot f$.$) . The eggs pass$ from the egg-tubes to the oviducts which unite posteriorly to form a common duct-the uterus $(U$.) and the vagina $(V$.$) . Uniting with the$ posterior portion of the uterus we have the bursa copulatrix (B.c.) enclosed in the anterior end of which is the receptaculum seminis (spermatheca) (R.s.) and bearing anteriorly also the accessory gland $(A . g$.$) .$

Repeated dissections of the reproductive organs of numerous females, both immature and mature, were made with the object of ascertaining definitely whether a slime or a pair of slime glands were present or not, but in all these I failed to observe any trace of them. (Such slime glands are present in the female reproductive organs of many Scolytids and 
usually enter the lower portion of the uterus (the vagina) prior to the entrance of the bursa copulatrix.)

According to Nusslin ${ }^{1}$ the bursa copulatrix in the genus Cryphalus is obscure or absent. From repeated dissections of the female reproductive organs in all stages of development for the purpose of investigating this point I should say rather that the receptaculum seminis is the obscure portion of the reproductive apparatus, for it is only in the reproductive organs of females that have just completed egg-laving that the position and outline of this part is traceable at all. In all stages of the development of the reproductive organs of the female I have found the bursa copulatrix quite easily discernible but at the same time there is no distinct line of demarcation between it and the receptaculum seminis. In my opinion the bursa copulatrix encloses the receptaculum seminis in its anterior end and this can be a possible reason for its obscurity.

The sequence of changes which I observed to take place in the reproductive organs of the female during their transition from the immature to the mature state and to their condition after egg-laying may be summarised as follows:

In the immature state (Fig. 12) the egg-tubes are colourless and are comparatively uniform throughout their length. The bursa copulatrix is colourless and empty while the receptaculum seminis enclosed within it is scarcely traceable. The accessory gland of the receptaculum is small and inconspicuous.

The first noticeable change in the reproductive organs is the slight narrowing of the lower portion of the egg-tubes while the contents of this portion become muddy coloured. Later some of this muddy coloured substance passes down into the oviduct which now becomes much swollen. Following on this, the egg-tubes, by a shunting-off process which takes place in the middle or posterior portion of each tube, become more elongated. Soon the egg-tubes divide up in bead-like fashion, each bead or egg-chamber containing an egg. In this stage, depicted in Fig. 13, we see that the oviduct is still swollen; the bursa copulatrix is full and is muddy in colour and the receptaculum seminis enclosed in the bursa copulatrix is still obscure. As soon as an egg has passed through the neck or lower portion of the egg-tube (see Fig. 14), this portion contracts, swelling out and contracting again each time an egg passes through it. From Fig. 14 it might seem that an egg is passed into the oviduct first from one ovary then the other in turn.

1 See Hopkins, p. 195. 
Egg-laying being completed the exg-tubes are now empty or contracted as shown in Fig. 15. The oviduct also is contracted while the outline of the receptaculum seminis enclosed in the anterior end of the bursa copulatrix is now traceable.

In the case of females which had completed egg-laying and had fed for a period of about four months prior to a possible second egg-laying, I found that, with the exception of a slight increase in the size of the terminal or nutritive chamber, the parts of their reproductive organs had undergone little further change in appearance.

In all my dissections of the reproductive organs of females both in the egg-laying and after egg-laying stages I failed to notice any trace of the so-called corpora lutea, or heap of degenerate yellowish tissue, which in many insects frequently collects at the bases of the eggchambers as soon as eggs have passed into the oviduct.

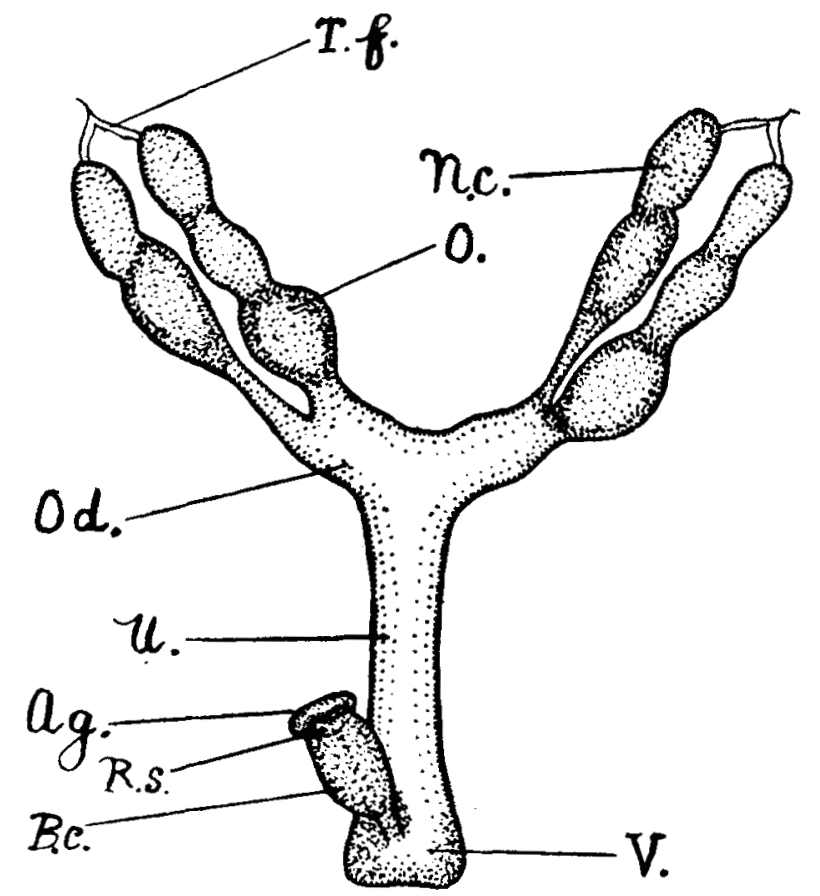

Fig. 14. Reproductive organs of female $C$, abietis egg-laying (greatly magnified).

In the following columns I emphasize the significant characters which appeared to be most useful in determining the unripeness and ripeness of the female reproductive organs. 
UNRIPE

The nutritive chamber at the apex of the egg-tubes is small and apparently seated directly on the oviduct.

Egg-tubes diminutive, short, not prominent, not separated off into ovarian chambers.

Bursa copulatrix empty. Gland associated with the receptaculum seminis empty.
RIPE

Nutritive chamber large.

Egg-tubes long and pointed so as to suggest strings of beads. The egg chambers increase in size gradually from the nutritive chamber to the oviduct.

Bursa copulatrix and gland associated with receptaculum seminis well filled.

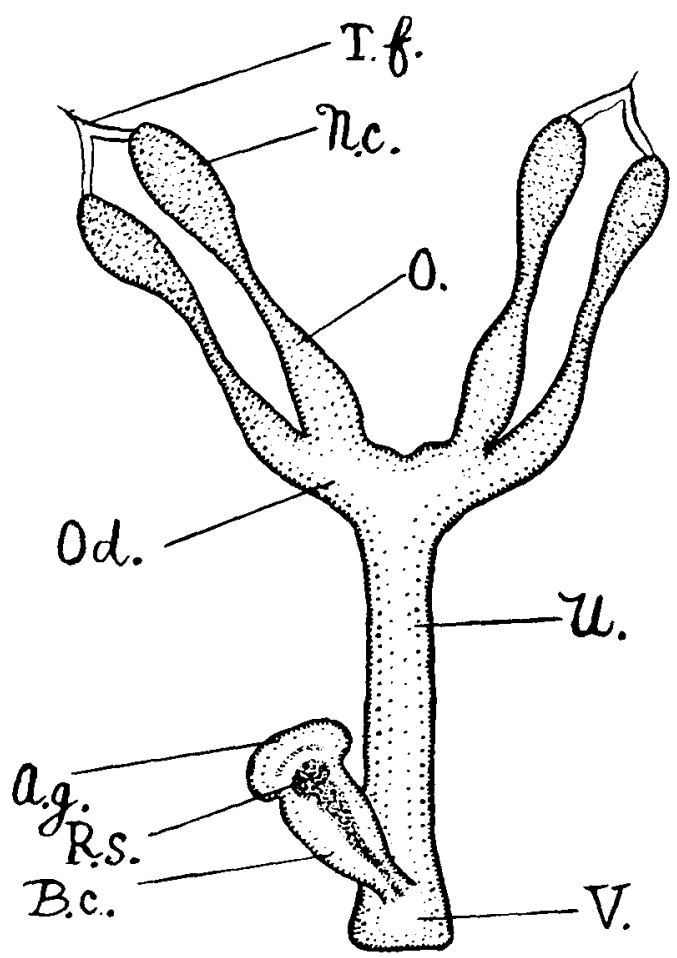

Fig. 15. Reproductive organs of female $C$. abietis after egg-laying (greatly magnified).

\section{QUESTION OF THE NUMBER OF GENERATIONS IN A YEAR.}

From repeated observations made in the open and from my experiments I am convinced that even under the most favourable conditions the occurrence of a double generation in the succession of parents, children and grandchildren within a single year is most unlikely. 
In Table No. I, I have summarised my observations and results of the control experiments already referred to under the paragraph dealing with the length of a life-cycle in a single generation. From this table it will be seen that the new generation developed from eggs laid in May of the year and issuing in September is unable to proceed to an egglaying, i.e. a new generation, in the same year. At the earliest it would be the next spring before they laid eggs. Similar results were also obtained from experiments and dissections from material bred in the open in the summer and autumn of the year 1917.

TABLE I.

\begin{tabular}{|c|c|c|c|c|c|}
\hline $\begin{array}{l}\text { Date of libera- } \\
\text { tion of adults } \\
\text { proceeding to } \\
\text { make gallery }\end{array}$ & $\begin{array}{c}\text { Boring mother } \\
\text { gallery }\end{array}$ & $\begin{array}{c}\text { Adult stage of } \\
\text { new generation } \\
\text { reached }\end{array}$ & $\begin{array}{l}\text { Reproductive } \\
\text { orguns of } \\
\text { females } \\
\text { dissected out }\end{array}$ & $\begin{array}{l}\text { Results of } \\
\text { microseopic } \\
\text { examination }\end{array}$ & Remarks \\
\hline $\begin{array}{c}2 \text { May } 1917 \\
\text { do. } \\
\text { do. }\end{array}$ & $\begin{array}{c}\text { 4 May } 1917 \\
\text { do. } \\
\text { do. }\end{array}$ & $\mid \begin{array}{c}27 \text { Sept. } 1917 \\
\text { do. } \\
\text { do. }\end{array}$ & $\left\{\begin{array}{c}9 \text { Oet. } 1917 \\
22 \text { Nov. } 1917 \\
3 \text { Iec. } 1917\end{array}\right.$ & $\begin{array}{l}\text { Immature } \\
\text { do. } \\
\text { do. }\end{array}$ & $\left\{\begin{array}{l}\text { Egg-laying would } \\
\text { not take place till } \\
\text { following spring as } \\
\text { little or no feeding } \\
\text { takes place in the } \\
\text { months Novem ber } \\
\text { to March }\end{array}\right.$ \\
\hline
\end{tabular}

Even adults derived from overwintering larvae and which issue in midsummer do not have a new generation in this year as is proved by the undernoted observations.

Some larvae that hibernated during the winter of 1916-17, the first of which pupated on June 5th, 1917, issued as adults from July 21st, 1917, to August 20th, 1917. The majority of these young adults however never swarmed at all during the year 1917 but remained underneath the bark where they were reared and hibernated the second winter as immature adults. That they were immature was proved from a large series of dissections made of their reproductive organs in November and December, 1917.

Some of the reproductive organs of those adults that did swarm in July and August of 1917 were also examined as the beetles issued from the material where they had been reared but they too were found to be immature. The others that issued I liberated on August 14th, 1917, in muslin cages enclosed within which were paraffined branches of Silver Fir, on which they could feed or breed as they chose. On the 16th of August, 1917, a number of them were found to be boring on the Silver Fir branches, evidently feeding. Examination of these branches was made at intervals up to Dec. 3rd, 1917, but in no case were eggs found in any of their 
borings. This is remarkable as a number of males and females were working together. The dissection of the reproductive organs of a number of these beetles on November 29th, 1917, and up to December 3rd, 1917, however showed that although they had been feeding for some time the reproductive organs were not ready for egg-laying.

\section{ARE TWO BROODS IN THE RELATIONSHIP OF BROTHERS AND SISTERS POSSIBLE IN A YEAR?}

My observations show that when the parent beetles have bred and their brood gallery is completed sometimes the male dies before the female has laid her last egg, the female beetle surviving. Very frequently the females die immediately after laying is completed and in many cases the males survive. In some cases both parents die, in others both survive after a first breeding. The mortality amongst parents that have already bred is considerable. Those survivors, male or female, tunnel galleries of a much similar appearance to those of the larval ones and feed on the gnawed material, obtaining nourishment from it and so recuperate their reproductive organs for a passible second egg-laying.

In my experiments a number of parent beetles that had completed egg-laying in the end of June, 1917, tunnelled and fed. The results of these experiments are shown in Table II.

TABISE $1 \mathrm{I}$.

\begin{tabular}{c|c|c|c|c}
\hline $\begin{array}{c}\text { Date of completion } \\
\text { of 1st egg-laying }\end{array}$ & $\begin{array}{c}\text { Found feeding in pseudo- } \\
\text { larval galleries after 1st } \\
\text { egg-laying }\end{array}$ & $\begin{array}{c}\text { Reproductive } \\
\text { organs of females } \\
\text { dissected out }\end{array}$ & $\begin{array}{c}\text { Result of } \\
\text { microscopic } \\
\text { examination }\end{array}$ & Remarks \\
\hline $\begin{array}{c}\text { 26 June 1917 } \\
\text { approx. } \\
\text { do. } \\
\text { do. }\end{array}$ & 2 July-20 Nov. 1917 & 20 Nov. 1917 & Immature \\
do. & do. & $\begin{array}{c}27 \text { Nov. } 1917 \\
3 \text { Dec. } 1917\end{array}$ & $\begin{array}{l}\text { do. } \\
\text { do. } \\
\text { do. }\end{array}$ & $\begin{array}{c}\text { A 2nd egg-laying } \\
\text { would not take } \\
\text { place if at all } \\
\text { till following } \\
\text { spring. }\end{array}$ \\
\hline
\end{tabular}

HOST TREES.

From observations made in the field I find that $C$. abietis confines itself in Scotland to breeding on the stems, branches and twigs of unhealthy, dying, or dead trees of three closely allied genera of conifers, namely, Abies, Picea, and Pseudotsuga. Like many other injurious insects $C$. abietis has a preference for certain genera and species, but if these are found wanting, deficient or in an unsuitable state for brood purposes others may be chosen.

My experience in Aberdeenshire, Kincardineshire and Midlothian leaves me with no doubt that $C$. abietis prefers, in Scotland at least, the 
genus Abies (Silver Fir family) for brood purposes, having a special preference for the species Abies pectinata D.C. (Common Silver Fir). I have also found Cryphalus breeding on Abies cephalonica Link. (Grecian Silver Fir) while in my breeding experiments the same insect readily took to Abies nordmanniana Spach. (Norman's Silver Fir), and Abies pinsapo Boissier (Spanish Silver Fir). It has also been recorded in Scotland on Abies nobilis Lindl., a North American species. It is possible that all the species of the genus Abies may be used for brooding purposes if in a suitable condition.

Next in order of preference, C. abietis takes the genus Picea (Spruce family), Picea excelsa Link. or Norway Spruce being the host plant on which I have found it.

Last in order but by no means of least importance C. abietis may choose for brood purposes the genus Pseudotsuga (Douglas Fir family). I have found the insect breeding freely in Aberdeenshire on the sickly branches of standing Douglas Firs, Pseudotsuga Douglasii Carr., the only species of the genus planted in this country.

We see then that $C$. abietis possesses a wide range of host trees, an exceedingly important factor which would have to be reckoned with in dealing with the control of the species.

As far as my observations go I am convinced that C. abietis in most cases only takes to the Spruce and Douglas Fir families when the preferred Silver Fir family is deficient or is in an unsuitable state for brooding purposes.

On the continent of Europe, according to Nusslin ${ }^{1}$ and other writers, C. abietis is typically a Spruce species. Nusslin also states that, although it prefers the species of the genus Picea it also takes the genus Abies and occasionally the genus Pinus. Of the species of the genus Pinus he states that it prefers Pinus strobus L. or Weymouth pine.

Kaltenbach ${ }^{2}$ quoting Ratzeburg names the species as attacking Pinus strobus and the dry branches of Silver Fir. Eichhoff ${ }^{3}$ names as host plants Spruce, Silver Fir and Pine.

\section{ECONOMIC IMPORTANCE OF C. ABIETIS IN SCOTTISH FORESTRY.}

Occasional references in the forest literature of Central Europe indicate that $C$. abietis has been known to be harmful especially if in numbers it attacked very young stems.

${ }_{1}$ Nusslin, Leitfaden der Forst Insektenkunde, 1905, pp. 201-2.

${ }^{2}$ Die Pfanzen-Feinde aus der Classe der Insekten, p. 685.

${ }^{3}$ Die Europaischen Borkenkafer, by W. Eichhoff, p. 177. 
So far as my observations in Scotland show, C. abielis has not proved of any great forest importance in the sense of having proved destructive to live trees, but the species must not be overlooked or observation on it neglected.

A knowledge therefore of its habits as well as the recognition of the presence of the beetle in our woods at the present time is opportune.

Its favourite breeding places are dead or almost dead trees, twigs and branches, of practically all ages, that have been spoiled or killed by some agency or other such as wind, breakage, etc. The positions most commonly chosen by the parent beetles for tunnelling their brood galleries are around twigs and branches, the female commencing her gallery in the axil of a side branch. No doubt she chooses this position because a good foothold is sccured for her while boring the entrance hole of the gallery. Boring gradually round the base of the side branch she euts the inner bark layers, namely the bast and cambium, leaving only the thin layer of outer bark. Where the twig or branch around which she has excavated her burrow or gallery is a small one it may be completely girdled and isolated from the main branch. Even when the twig or branch is strong and although only partially girdled by one gallery it may be completely girdled and isolated from the main branch or stem by other galleries. Were such workings then to be cut on living twigs and branches it is quite evident that serious damage would be done to trees, for no food material from these isolated portions could pass down to the main stem and roots.

A point worthy of mention in connection with $C$. abietis is that it is negatively heliotropic, the parent beetles preferring bushy twigs and branches in shady places unexposed to the sun. For example, the topmost branches of heaps of brushwood lying in the open are not commonly chosen for brood purposes, while the lower branches of such heaps as well as entire heaps in the shade of standing trees may be badly infested. Most likely those branches which are exposed to the sun are too dry for breeding on and this can be a reason why they are not chosen by the parent beetles.

To ascertain if beetles are present in a wood one has only to examine carefully the axil of a dead twig or branch, when, if beetles are at work, a minute heap of fine bore dust, reddish yellow in colour, will be seen. If a number of beetles have issued a series of minute exit holes may be seen at irregular intervals on the surface of the bark. Frequently one will find on examination of branches where the majority of the beetles 
have issued that the outer bark layer is broken and the wood surface exposed to view.

\section{NATURAL ENEMIES OF C. ABIETIS.}

From observations made in the field during the last two years I am of the opinion that the bark fungi play little or no part in controlling the numbers of $C$. abietis. Only on a few occasions have $I$ found beetles killed by fungoid attack.

The larvae are destroyed in numbers by the larvae of a Hymenopterous parasite belonging to the family Chalcididae. On the removal of a piece of the outer bark layer of a badly infested branch or twig one repeatedly met this parasite either in the larval or pupal stage. Only one parasitic larva was found on each host. No cocoon is spun by this Chalcid larva prior to pupation but the pupa lies naked in the Cryphalus gallery or pupal bed. As soon as these parasites have reached the adult stage each gnaws a minute puncture through the outer bark and escapes into the open.

From some Silver Fir branches badly infested with $C$. abietis which I collected in Aberdeenshire in October, 1916, large numbers of these Chalcids issued from July 21st to August 6th, 1917, just at a period when large numbers of these $C$. abietis larvae would be found on infested branches.

The number of these Chalcids varied to a great extent in different localities. From one lot of badly infested material collected in one particular area in the Aboyne district only a few parasites issued. On the other hand, from badly infested material collected from another area a little over a mile from the first exceedingly large numbers of parasites issued. In a single day as many as 30-40 individuals escaped from a few pieces of badly infested material. In this particular case I estimate about 75 per cent. of the larvae of the beetles must have been destroyed.

The abnormal conditions prevailing in our forest areas during the past three years have undoubtedly been the means of creating an excessive number of breeding places for our bark-boring beetles. Foresters throughout the country ought therefore to be on the alert. The intensive study of the life-history and habits of this beetle and of other such forms is for this reason of more than usual interest at the present time.

In conclusion my thanks are due to Dr R. Stewart MacDougall for the encouragement and facilities he has given me throughout this work. 